\title{
Indian Rivers Seen by the Greeks in the Roman ImPerial Period: from Geographical Precision to Exotic Dreams
}

\author{
Claire Muckensturm-Poulle \\ Université de Franche-Comté \\ claire.poulle@dbmail.com
}

Received: 29-11-2014

Accepted: 27-01-2015

\begin{abstract}
The image of Indian rivers given by Greek authors in the Roman imperial period depends on the literary genre they chose : specialists of geography and history like Strabo or Arrian wonder about the reliability of the observations formerly made by the companions of Alexander about the Indus and its tributaries (dimensions, floods, delta, flora and fauna, resemblance to the Nile). A novelist like the pseudo-Callisthenes, and a polemicist like Palladios try, for their part, to amaze their readers with the mirabilia found in the Ganges or in the Tiberoboam. They imagine that their paradisiacal banks offer an ideal living environment to the Brahmans.
\end{abstract}

Keywords: Indus, Ganges, Tiberoboam, Nile, Alexander, Brahmans, marvels, cartography

RESUMEN Los ríos indios vistos por los griegos de la época romana imperial: de precisiones geográficas a sueños exoticos

La imagen de los ríos indios que construyen los autores griegos de época romana imperial depende del género literario en el que se expresen : los especialistas de geografía y historia como Estrabón o Arriano se preguntan acerca de la verosimilitud de las antiguas observaciones efectuadas por los compañeros de Alejandro a propósito del Indo y de sus afluentes (sus dimensiones, crecidas, los deltas, su fauna y flora, sus similitudes con el Nilo). Por su parte, un escritor de novela (pseudoCalístenes) y un polemista (Paladio) buscan sorprender a sus lectores recurriendo a las mirabilia relacionadas con el Ganges o el Tiberoboam. Estos ríos paradisíacos son imaginados como el marco de vida ideal para los Brahmanes.

PALABRAS ClAVE: Indo, Ganges, Tiberoboam, Nilo, Alejandro, Brahmanes, maravillas, cartografía

From the fifth century $\mathrm{BC}$, through the work of the historian Herodotus, the Greeks were aware that there was in India a river that supplied raw fish for the food of the fishermen who lived on its banks, gigantic reeds for their boats, and rushes from which they made their clothes (Histories, 3.98). At the beginning of the fourth century BC, the Greek historian Ctesias, who was a physician at the court of the Persian king Artaxerxes, recorded in his Indika all that he had heard about India. He mentions two rivers: the Indus, which accommodates an immense worm in its waters (Indika, F45.1), and the Hyparchos which 
carries amber (Indika, F45.36). During the years 326-325 BC, the military expedition of Alexander in India gave the Greeks the opportunity to know more about the Indus Basin. Through the testimony of the historians who accompanied Alexander in his oriental conquests, the Greeks were soon aware that in 326 BC Alexander had crossed successively the Indus, the Hydaspes (Jhelum), the Acesines (Chenab), and the Hydraotes (Ravi); that he had reached the banks of Hyphasis (Sutlej) but that his soldiers had forced him to turn back; that he had crossed the Hydraotes and the Acesines again; that with a fleet of 2000 vessels, he had sailed down the Hydaspes, the Acesines, and the Indus; that he had reached Pattala (Hyderabad) in January 325; and that he had decided to go back to Persia in August 325.

However, these testimonies by the companions of Alexander have come to us only as fragments — edited by Jacoby (1927) and translated into French by Auberger (2005) —or allusions that we can find in works from the Roman imperial period. Indeed, Alexander's adventure in India never stopped fascinating Greek writers in the Roman Empire. Through four works of that period, the Geography of Strabo, the Anabasis of Arrian, the Alexander Romance by the pseudo-Callisthenes, and the Letter about the Brahmans by Palladios, all belonging to various literary genres, I will discuss what they retain from older information about Indian rivers and how they completed or distorted it.

Let us first look at Strabo's work: this geographer, who lived during the Augustan period (24 $\mathrm{BC}-14 \mathrm{CE}$ ), decided to write a description of the inhabited earth. While he meticulously describes the lands closest to Rome, he deals more quickly with the borders of the world, which were of no immediate political interest for the Roman government. However, he considers that the description of the borders of the world has an intellectual use, because it brings to the men of culture the knowledge that will make them real philosophers.

That is why he describes India in the first chapter of the fifteenth book of his Geography. To give a precise idea of this distant country, he prefers not to trust travel accounts by contemporaries of his who had sailed to India. Although he knows that the maritime trade between India and the Western World had increased since the Roman conquest of Egypt (see Geography, 2.5.12 and Young 2001), Strabo is not interested in the practical considerations of traders:

For the merchants who now sail from Aegypt by the Nile and the Arabian Gulf as far as India, only a small number has sailed as far as the Ganges; and even these are merely private citizens and of no use as regards the history of the places they have seen. (Geography, 15.1.4) 
Instead of quoting guidebooks written by uncultured traders who know only a few coastal cities of India, Strabo prefers to resort to the older, more learned works by Eratosthenes, Megasthenes, and the historians who had been companions of Alexander. These authors used Indian rivers to define the limits of India and to structure their description.

At first, Strabo refers to the geographer Eratosthenes of Cyrene $\left(3^{\text {rd }}\right.$ century BC) to give the shape of India: it is a parallelogram, the limits of which he can define (see figure 1). Its northern boundaries are the mountains called Caucasus by the Greeks and the Ganges; its western ones are the Indus, while its southern and eastern ones are the outer sea that the Greeks call the Atlantic Ocean. In this simplified view of India, the sea and the rivers play an important role in the definition of space. On one side, the Indus defines the western limit by forming a demarcation line with Ariane (a western region which at the time of Alexander was a part of the Persian Empire); on the other side, the line of the maritime bank serves to clarify the shape of India; the Southern coast follows the parallel of Meroe, with a gigantic cape in the East, advancing southward.

To define the Indian space more precisely, Eratosthenes wanted to specify the dimensions of each of the sides of the parallelogram, allowing that

each of the greater sides exceeds the opposite side by as much as three thousand stadia, which is the same number of stadia by which the cape common to the eastern and southern coast [i.e. Cape Comorin] extends equally farther out in either direction than the rest of the shore. (Geography, 15.1.11)

The western side of India, from the Caucasian Mountains (i. e. the Hindu Kush) to the southern sea is estimated at 13000 stadia. As a stadium is approximately $180 \mathrm{~m}$, the length of the Indus, according to Eratosthenes, would be $2340 \mathrm{~km}$, which is well below its actual length of $3180 \mathrm{~km}$. On the other hand, Eratosthenes is closer to reality when he indicates the southnorth size of the oriental side of India: 16000 stadia, or $2880 \mathrm{~km}$. For its length from west to east in the North, Eratosthenes gives an approximate dimension: indeed, it was possible for him to estimate exactly the first segment of this line from the Indus to Palibothra, because there was a royal road of 10000 stadia $(1800 \mathrm{~km})$. The second part, however, from Palibothra to the mouth of the Ganges, is a matter of guesswork, depending on the voyages made on the Ganges from the sea to Palibothra; and this would be something like six thousand stadia. So the total east-west length of India, as a minimum, will be 16000 stadia. As Jacob (1991) noticed, Strabo does not doubt the exactness of these complex calculations of Eratosthenes, which he uses to reduce the complexity of the space described by Megasthenes and the companions of Alexander to a simple geometric form. 
Secondly, Strabo describes the Indus Basin and the Ganges Basin. To study the Indus area, he relies on the Indica written by Alexander's companions, which help him to find characteristics common to all the rivers of this basin: they are big and wide, and their waters are fertile. To characterize them better, Strabo borrows from Alexander's companions the comparison which they made between these rivers and the Nile: both rivers have a regime of big floods. Just as Egypt is "a gift of the Nile" (see Herodotus, Histories 2.5), so the alluvial plains of the Punjab are fertilized by the floods of the Indus and its tributaries. According to the historian companions of Alexander, these floods may be explained by the same meteorological phenomenon of the summer rains that fall on the upstream waters of those rivers. Furthermore, in Egypt and in India the sun increases the fertility of the air, the water and the soil. The double action of the floods and the sun create in both countries a very similar fauna (except for the hippopotamus ${ }^{1}$ ). Nevertheless, as the climate of India is wetter than that of Egypt, Indian animals are bigger than Egyptian animals. The florae produced by the Nile and the tributaries of the Indus are similar too, particularly the aromatic plants and the water lenses. That is why Nearchus, the admiral of Alexander's fleet, states:

when Alexander saw crocodiles in the Hydaspes and Aegyptian beans in the Acesines, he thought he had found the sources of the Nile and thought of preparing a fleet for an expedition to Egypt. (Geography, 15.1.25)

As Schneider (2004, 38-9) writes, Artaxerxes Ochos thought before Alexander that the Nile had an oriental origin. This Persian king had the project of diverting the course of the Indus, which he thought identical to the upper course of the Nile, with the aim of conquering Egypt (see Liber de inundatione Nili). Alexander probably wanted to sail down the Indus to the Nile. But as soon as he learned from Indians that the Indus did not run into Egypt, but emptied itself into the South Sea by two mouths, he realized his error and gave up his project of a river expedition to Egypt (Geography, 15.1.25).

After these general observations, Strabo describes in great detail each of the territories bounded by the rivers of the Punjab. Like the Itineraria navigationis, he enumerates kingdoms, cities, peoples, plants and animals that the Macedonians discovered as they progressed eastwards and then southwards.

To spare his readers a boring catalog, Strabo insists on the astonishment of Alexander's companions when they realized the strangeness of Indian rivers: their banks accommodate an

\footnotetext{
1 The historian companions of Alexander did not agree about the hippopotamus: "Onesicritus was the only one saying that the hippopotamus is also to be found in India" (Strabo, Geography, 15.1.13)
} 
extraordinary flora and fauna, which gives Strabo the opportunity to describe various types of marvels (thaumata). Some trees are marvels because of their gigantic size:

Aristobulus also, where he mentions the Acesines and its confluence with the Hyarotis, speaks of the trees that have their branches bent downwards and of such size that fifty horsemen (according to Onesicritus four hundred!) can pass the noon in shade under one tree (Geography, 15.1.21).

Such dimensions probably seemed to be unreal to the readers of Strabo. But there are actually gigantic banyan trees in India. For example, the great banyan, a Ficus benghalensis located in Acharya Jagadish Chandra Bose Indian Botanic Garden is the widest tree in the world. The circumference of the original trunk was $1.7 \mathrm{~m}$, and from the ground it measured $15.7 \mathrm{~m}$. The area occupied by the tree is about 1.5 hectare or 4 acres. The present crown of the tree has a circumference of nearly half a kilometer and the highest branch rises to about $25 \mathrm{~m}$.

Animals (dogs, elephants, monkeys) observed by the companions of Alexander were also extraordinary in size. Furthermore, they behaved in extraordinary ways; for example, the great apes which the troops of Alexander met between Hydaspes and Acesines behaved like soldiers:

once the Macedonians, seeing many of these long-tailed apes (cercopitheces) as in front-line array on some bare hills (for this animal is very human-like in mentality, no less so than the elephant), got the impression that they were an army of men; and they actually set out to attack them as human enemies, but on learning the truth from Taxiles (the king of Taxila), they desisted. (Geography, 15.1.29)

The marvel consists here in a confusion between the world of animals and the world of men. Like shy animals, the monkeys should have to run away at the approach of the troops of Alexander. But their physical and intellectual closeness to men inclined them to adopt a behavior suited to the war situation in which they found themselves.

Another type of marvel consists in the fact that an animal possesses a quality appropriate to its species to such a degree that it seems to belong to another species. For example, the enormous dogs that Sopeithes (one of the provincial chiefs of the country between Acesines and Hyarotis) had offered to Alexander showed themselves as brave as the lion they had to fight:

The match (between the dogs and the lion) having become equal, Sopeithes bade someone to take one of the dogs by the leg and pull him away, and if the dog did not yield to cut off his leg... and the dog suffered the cutting of his leg by slow amputation before he let go his grip. (Geography, 15.1.31)

The people who live in the Indus Basin are also characterized by their excesses: for example, the Brahmans that Onesicritus, the pilot of Alexander's ship, met between the Indus and the 
Hydaspes, practice an asceticism more rigorous than Cynics in the Greek world. (Geography, 63-65). The Cathaeens who live between the Hydaspes and the Acesines have developed a great liking for beauty:

Onesicritus says that they choose the handsomest person as king... and that the men dye their beards with many most florid colors for the sole reason that they wish to beautify themselves. (Geography, 15.1.30)

The Greeks, who have beauty and goodness in men (kaloi kagathoi) as an ideal would appreciate beauty too, but not to the same extent as the Cathaeens. These remarks are not only decorative: Strabo also wants to incite his readers to adopt a comparative perspective.

When Strabo describes the Ganges Basin, he inevitably has to resort to other sources than the writings of Alexander's companions. He uses two writers of the Hellenistic period, Megasthenes and Artemidorus. Megasthenes was an ambassador of Seleucos the First at the court of King Sandrocottos (Chandragupta) in Palibothra in the first years of the third century BC. Strabo refers to him to place Palibothra at the confluence of the Ganges and the Erranoboas i.e. the Yamuna (see Geography, 15.1.36). The geographer Artemidorus of Ephesus (who lived at the end of the second century BC) appears to him to be unclear; Strabo uses him nevertheless to say that the Ganges flows down from the Emoda mountains (the Himalayas) towards the south; and that one of its tributaries, the Oedanes, breeds both crocodiles and dolphins. This ecological precision has led historians of geography to think that the Oedanes is the Brahmaputra, the delta of which is invaded by the sea.

Besides the Indus and the Ganges, Strabo mentions another river, the Silas, which flows in the extreme north of India. Quoting Megasthenes, he says that the waters of this river may have the magic property of preventing any body from floating. As Karttunen (1989) noticed, this assertion coincides with a scholion of NimiJâtaka 541, v. 424-425:

Uttarena nadi sidā gambhirā duratikkamā,

Naḷaggivaṇnā jotanti sadā kañcanapabbatā.

'Sîdâ's a river in the north, unnavigable, deep:

About it, like a fire of reeds, blaze golden mountains steep, unnavigable, explains the scholiast, "because the water is so delicate, that even a peacock's feather will not float, but sinks to the bottom." (transl. Cowell 2014).

To conclude his description of India, Strabo stresses the wealth of all the rivers of India: they bring down gold-dust like Iberian rivers (Geography,15.1.69). With this comparison to Spanish rivers, Strabo makes India an El Dorado, the object of many later projects of conquest. 
Arrian of Nicomedia, who lived in the second century AD, was an important general in the Roman army. In the Anabasis he tells the story of Alexander, from his coming to the throne to his death. Arrian structured the narrative by making the limits of each book correspond with the borders that the Conqueror successively crossed. Thus, the fifth book takes Alexander from Indus to Hyphasis; the sixth book deals with his return to Hydaspes, his descent of it by boat to the southern sea, and his return to Persepolis. This narrative, a retelling of old events, is based on the writings of two companions of Alexander, the engineer Aristobulus and the general Ptolemy. As a good officer who likes the accuracy of military reports, Arrian borrows from his sources all the indications that give a precise idea of Indian topography, and in particular the rivers of the Punjab. Every time the narrative requires precision, he indicates the width of rivers crossed by Alexander and the strength of their current. He also indicates that the Acesines (Chenab) is 15 -stade $(2.7 \mathrm{~km})$ wide at the point where Alexander crossed it, "that his current is very swift, with great, sharp rocks; the water rushes down over them, billowing and roaring" (Anabasis, 5.20.8). The Hydraotes (Ravi) is as broad as the Acesines but not so swift in current (Anabasis, 5.21.4). It is much easier to cross.

For the long river journey to the South, Arrian, basing himself on Ptolemy, indicates the number and shape of the vessels built by Alexander (Anabasis, 6.2.4). He also notes that the Greek pilots had to adapt their navigation technique to the regime of rivers. For example, when they reach the turbulent confluence of the Hydaspes and the Acesines,

the steersmen directed the sailors to row as strenuously as possible and get out of the narrows, so that the ships might not be caught in the whirlpools and be capsized by them, but that they should master the eddies of the water by their rowing (Anabasis, 6.5.1)

But Arrian does not retain the technical precision of his sources. Furthermore, he is attracted to the human element in the Greek invaders' adventure. That is why he tries to reconstitute the atmosphere of this Indian campaign. Like a filmmaker creating fictitious documentaries, Arrian describes, for example, the quiet departure for the great sea:

there was nothing like the sound of the rowing, with so many ships rowing at one and the same moment, and the shouts of the boatswains giving the time for every stroke, and of the rowers when they struck the foaming water all together and huzza'd. (Anabasis, 6.3.3)

As if making the soundtrack of a documentary, Arrian suggests here a contrast with the cacophony of the first crossing of the Hydaspes, a few months earlier, "during the night, when the thunder-claps and the rain counteracted the clatter of the arms and the commotion arising from the commands" (Anabasis, 5.12.3) 
However, the experience of the soldiers matters less for Arrian than the character of their leader. Indeed, the accounts of crossing or sailing on the Indian rivers are especially used to emphasize the exceptional qualities of Alexander. The conqueror is at first a remarkable strategist who prepares the crossings of rivers by a meticulous exploration of the topography: for example, he prepares the first crossing of the Hydaspes, noticing a wooded headland that faces a wooded island, "both places being suited to hide the attempt at crossing." (Anabasis, 5.11.1).

Furthermore, Alexander does not hesitate to employ stratagems to deceive the enemy. Before he crossed the Hydaspes, he took the greater part of his cavalry in this and that direction along the banks, with shouts and war-cries. When this had been going on for some time, the Indian king Porus stopped following the directions in which the cavalry moved. So the Indian scouts warned Poros too late when Alexander really crossed the Hydaspes (Anabasis, 5.3.4).

Alexander is also an excellent warrior who gives his soldiers an example of great physical courage, often leading the most risky operations: thus he is the first to get to the other side of the Hydaspes (Anabasis, 5.13.2).

Alexander thus takes risks for himself, but on the other hand he knows also how to protect the lives of his men: he saved the survivors among the sailors who had been shipwrecked in the confluence of the Hydaspes and the Acesines (Anabasis, 6.5.4). Alexander wants to be on good terms with his soldiers. He also wants to be on good terms with the gods. That is why he offers to his gods a propitiatory sacrifice every time the crossing of a river looks dangerous (before crossing the Indus in Anabasis, 5.3.6.; before crossing the Acesines again in Anabasis, 5.29.5) and a sacrifice of thanksgiving each time he safely arrives on the other bank (for example in Anabasis, 5.20.1). When he reaches the edge of Hyphasis, the negative judgment of the soothsayers after examination of the sacrificial entrails corresponds, as if by magic, to the refusal of the Macedonian soldiers to go further east (Anabasis, 5.28.4). Alexander can thus order his army to turn back without losing face.

As Bosworth (1995) says in his commentary, Arrian uses the historian companions of Alexander to make his account credible and lively. He paints the laudatory portrait of a fearless conqueror who regards the Indian rivers sometimes as obstacles, sometimes as good ways to travel.

In the third century $\mathrm{CE}$, an anonymous writer called the pseudo-Callisthenes composed in Alexandria The Life and Deeds of Alexander of Macedon, a fictionalized biography we call the recensio vetusta of the Greek Alexander Romance. The conquest of India is treated in eight chapters of the third book, a small space compared with the 126 chapters of the whole 
romance.

For the Indian episode, the pseudo-Callisthenes follows approximately the chronological order, but local or temporal precision does not matter to him. The only Indian river he mentions by name is the Hydaspes: "It runs into the countries of the East governed by a very powerful king" (Greek Alexander Romance, 3.4). The novelist mistakes here the Hydaspes, at the bank of which Alexander defeated Poros, for the Hyphasis, beyond which his troops refused to follow him; furthermore, the sovereign about whom he speaks seems to be the powerful king of Maghada who reigned over the high valley of the Ganges, was capable of mobilizing an immense army, and frightened the Macedonian troops. In spite of the historical reality, the novelist asserts that Alexander decided to campaign against this powerful king. But Alexander is wounded when attacking a city, which incites him to give up the conquest.

From that moment, he wants rather to discover the curiosities of India. He writes a long letter about them to his former teacher Aristotle ${ }^{2}$ (Greek Alexander Romance, 3.17 i. e. Supplement $I$ in the translation of Stoneman 1991). This letter breaks the linearity of the account, but it allows the novelist to accumulate marvel upon marvel. Alexander says he saw a city built on stilts of bamboo in the middle of a river. The soldiers wanted to drink the water of the river, but it was more bitter than hellebore. According to some commentators, this is characteristic of non-Indian rivers, notably salty rivers of the Touranian plain (see Bounoure, Appendix 1, note 27). All buildings of the city were made from bamboo. The city itself was hidden by immense bamboo walls and defended by bamboo dugouts which recalled the dugouts of reeds already mentioned by Herodotus. A few soldiers of Alexander tried to swim to this extraordinary city, but hippopotami came and seized the men. Therefore, the pseudoCallisthenes superimposed different images of exotic rivers to invent a strange river, very protective towards the natives and very hostile towards the foreigners.

But this episode of the forbidden river city is also the result of the crossing of various literary genres. Historical and real ethnographic data may be the starting point: it may well be that Alexander really saw on the bank of an Indian river a city of fishermen, built on piles. From these data, the pseudo-Callisthenes developed a wonderful universe where the river city becomes a forbidden city defended not only by human sentinels, but also by hippopotami who are almost as terrible as the monstrous man-eaters of the Homeric epic. This poikilia (variegation) is typical of the Greek novel.

\footnotetext{
2 There were several letters of Alexander to Aristotle in the Greek world; either as independent papers, or included in the various versions of the Alexander romance.
} 
Palladios, who lived from $363 \mathrm{CE}$ to $431 \mathrm{CE}$ ) was a Christian monk, and later the bishop of Helenopolis in Bythinia, in the North-West of modern Turkey. He wrote at the end of the fourth century a letter On the Peoples of India and the Brahmans, which under the mask of exoticism was a way for him to denounce bad Christian monks.

This letter consists of two parts: in the first one, Palladios admits he has not gone personally to the country of the Brahmans, which he locates not far from India and from China, along the Ganges. He specifies that the Ganges is a river which is called in the Bible the Phisôn, "one of the four rivers which were gushing from paradise" (On the Peoples of India and the Brahmans, 1.1). Palladios probably found this equivalence between the Ganges and the Phisôn in the Antiquities of the Jews of Josephus. The Jewish historian of the first century CE actually wrote that "the Phison, which denotes abundance, running into India, makes its exit into the sea and is by the Greeks called Ganges" (Antiquities of the Jews 1.3). By this biblical allusion, Palladios suggests that the banks of the Ganges are somehow paradisiacal.

Palladios then describes the country of the Brahmans, using the testimony of a contemporary lawyer, a native of Thebes in Egypt, who stayed for a long time at Taprobane (Sri Lanka) and in India. According to this lawyer, the Brahmans live naked near the river. They possess nothing, spend their time praying, and live on food gathering and fresh water. The male Brahmans live on the bank of the river which is near the Ocean, the female Brahmans on the bank which borders on India. Nevertheless, the male Brahmans cross the river in the summer and stay for forty days with their wives to have children (On the Peoples of India and the Brahmans, 1.11-13).

The Ganges thus plays an important role in birth control and in the demarcation of the territories which belong to each gender of Brahmans. To insist on the bordering function of the river, the Theban lawyer indicates that the Ganges is extremely difficult to cross, because it is infested with odontotyrannoi, who are monstrous amphibians (perhaps gharials ${ }^{3}$ ) capable of gobbling up an elephant. But luckily these monsters leave the river when the Brahmans visit their wives. The banks of the Ganges also accommodate snakes 70 cubits long, big ants, huge scorpions, and crowds of elephants. Although the Theban lawyer probably never read the historian companions of Alexander, he resorts to the same clichés about the harmfulness and hugeness of the Indian fauna.

Palladios organizes the second part of his letter as a dialog between Dandamis, leader of the Brahmans, and Alexander. This dialog refers to the testimony of Onesicritus, but in a very

\footnotetext{
${ }^{3}$ The gharial (gavialis Gangeticus) is one of the longest of all living crocodilians, measuring up to $6.25 \mathrm{~m}$, but it is fish-eating.
} 
indirect way, being content with recalling that Onesicritus was Alexander's emissary. In the dialog of Palladius, Dandamis contrasts the unlimited ambition of the Conqueror with the wisdom of the Brahmans. These wise men know how to content themselves with little, are on a vegetarian diet, and drink only the pure water of a river which Dandamis calls Tiberoboam. Tiberoboam is probably a corruption of Erannnoboas, which Megasthenes named as the main tributary of the Ganges (see Arrian, Indica 4.3 and 10.5). Filliozat (1986) thinks that Erannoboas is the Tungabena in the Decan. Desantis (1992, $60 \mathrm{n} 44)$ suggests identifying this river with the Ghagra, a tributary on the left side of the Ganges. Dandamis contrasts his extreme sobriety to the taste for luxury shown by Calanos, the bad Brahman who did not hesitate to leave the banks of Tiberoboam to follow Alexander to Persia (On the Peoples of India and the Brahmans, 2.4).

Palladios thus uses the figure of Calanos to chastise the bad monks who give up their vows to return to the profane world. Dandamis, on the contrary, represents the good monk: by drinking "the water of wisdom" of the Tiberoboam, he attains the wisdom of a life lived in sobriety and conformity to nature.

Thus, the Ganges and the Tiberoboam form an exotic and a symbolic decor in the Letter about the Brahmans: they entertain the reader with their marvelous fauna, but they suggest at the same time that paradise can only be found in renunciation.

To conclude, the information given by our four writers of the Roman imperial period obviously depends on their literary project. The geographer Strabo and the historian Arrian follow closely the companions of Alexander to give precise details on Indian rivers. The novelist pseudo-Callisthenes and the polemicist Palladios make them an exotic decor and a reservoir full of marvels. But all insist on the strangeness, the immensity and the dangerousness of the rivers of the "Far-East": so they were developing clichés which were to continue after antiquity.

\section{WORKS CITED}

Arrian, Anabasis Alexandri, Books 5-7, transl. by Brunt, Peter AstBury (1983), The Loeb Classical Library, Cambridge Mass: Harvard University Press, William Heinemann Ltd.

Auberger, YAnNick (2005), Historiens d'Alexandre, collection Fragments, Paris: Les Belles Lettres. 
Bosworth, Albert (1995), Commentary on Arrian's History of Alexander, vol.2, Oxford: Clarendon Press.

COWELl, EdWARD B. (2014), new ed., The Jâtaka or Stories of the Buddha's Former Births, vol.6, Delhi: Motilal Banarsidass Publishers, 55-6.

Ctesias, La Perse. l'Inde. Autres fragments, ed. and transl. by Lenfant, DominiQue (2004), Collection des Universités de France, Paris: Les Belles Lettres.

Filliozat, Jean (1986), L'Inde vue de Rome, Paris: Les Belles Lettres.

Herodotus, Histories, vol. 2, transl. by Godley, Alfred Denis (1921), The Loeb Classical Library, Cambridge Mass: Harvard University Press, William Heinemann Ltd.

JACOB, Christian (1991), Géographie et ethnographie en Grèce ancienne, Paris: Armand Colin.

JACOBY, FelIX (1927), Die Fragmente der Griechischen Historiker, II B; II D, Berlin: Weidmann.

Josephus, The Jewish Antiquities, vol. 1, transl. by THACKerAy, Henry ST. John (1930), The Loeb Classical Library, Cambridge Mass: Harvard University Press, William Heinemann Ltd.

Karttunen, Klaus (1989), India in early Greek literature, Helsinki: the Finnish Oriental Society.

Palladios, I genti dell' India e i Brahmani, transl. by Desantis, GIOVAnNi (1992) Roma: Città nuova.

Pseudo-Callisthenes, Le Roman d'Alexandre, transl. by Bounoure, Gilles (1992), coll. La roue à livres, Paris: Les Belles Lettres.

, The Greek Alexander Romance, transl. by STONEMAN, RichARD (1991), London: Penguin Books.

SCHNEIDER, PIERRE (2004), L'Ethiopie et l'Inde. Interférences et confusions aux extrémités du monde antique,Rome: Ecole française de Rome.

Strabo, Geography, vol. 1 and 7, transl. by Jones, Horace, LeOnARD (1966), The Loeb Classical Library, Cambridge Mass: Harvard University Press, William Heinemann Ltd.

Young, GARY KeIth (2001), Rome's Eastern Trade: International Commerce and Imperial Policy, 31BC-AD305, London: Routledge. 


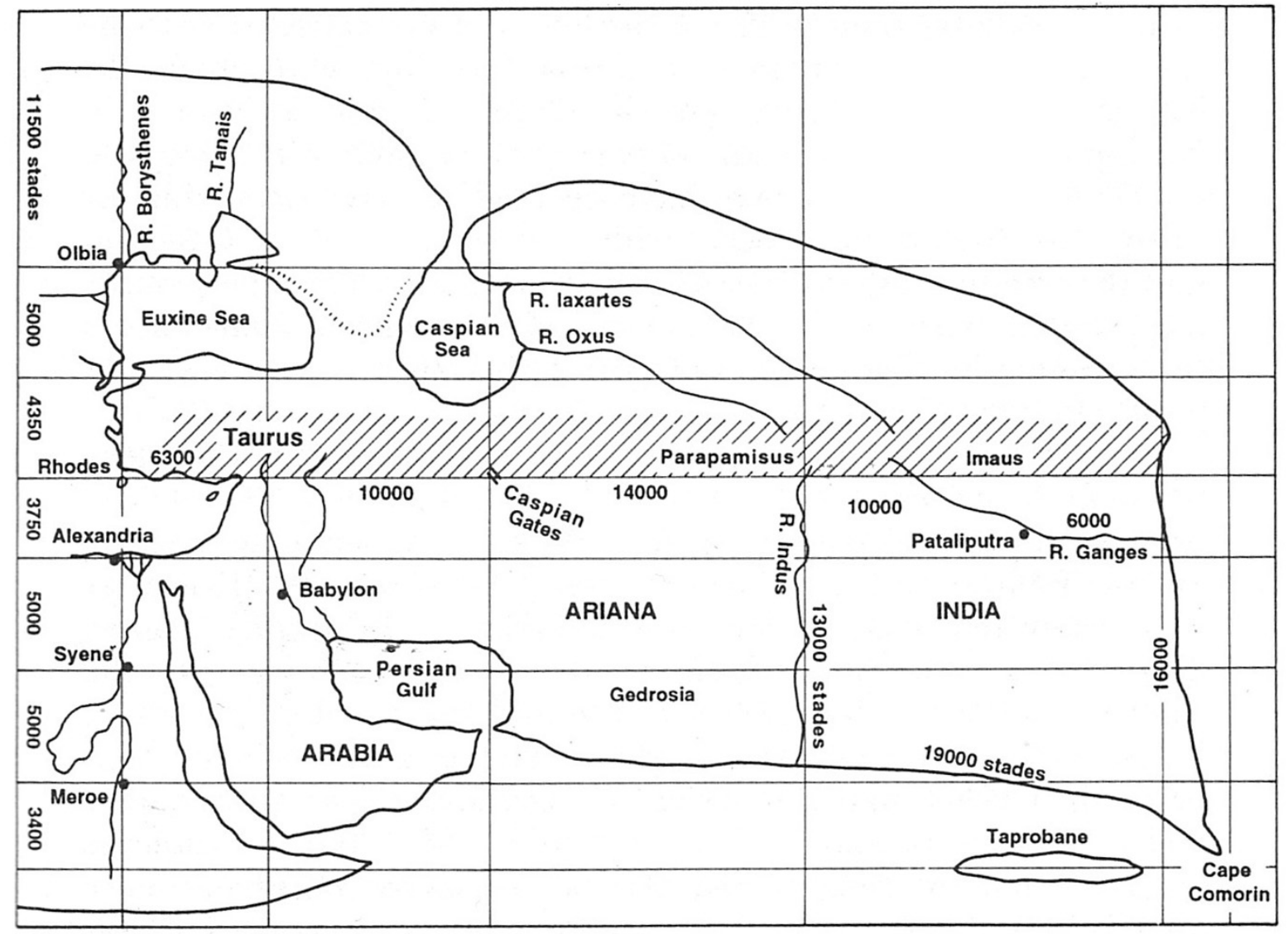

Fig. 1. Eratosthenes' picture of the East 


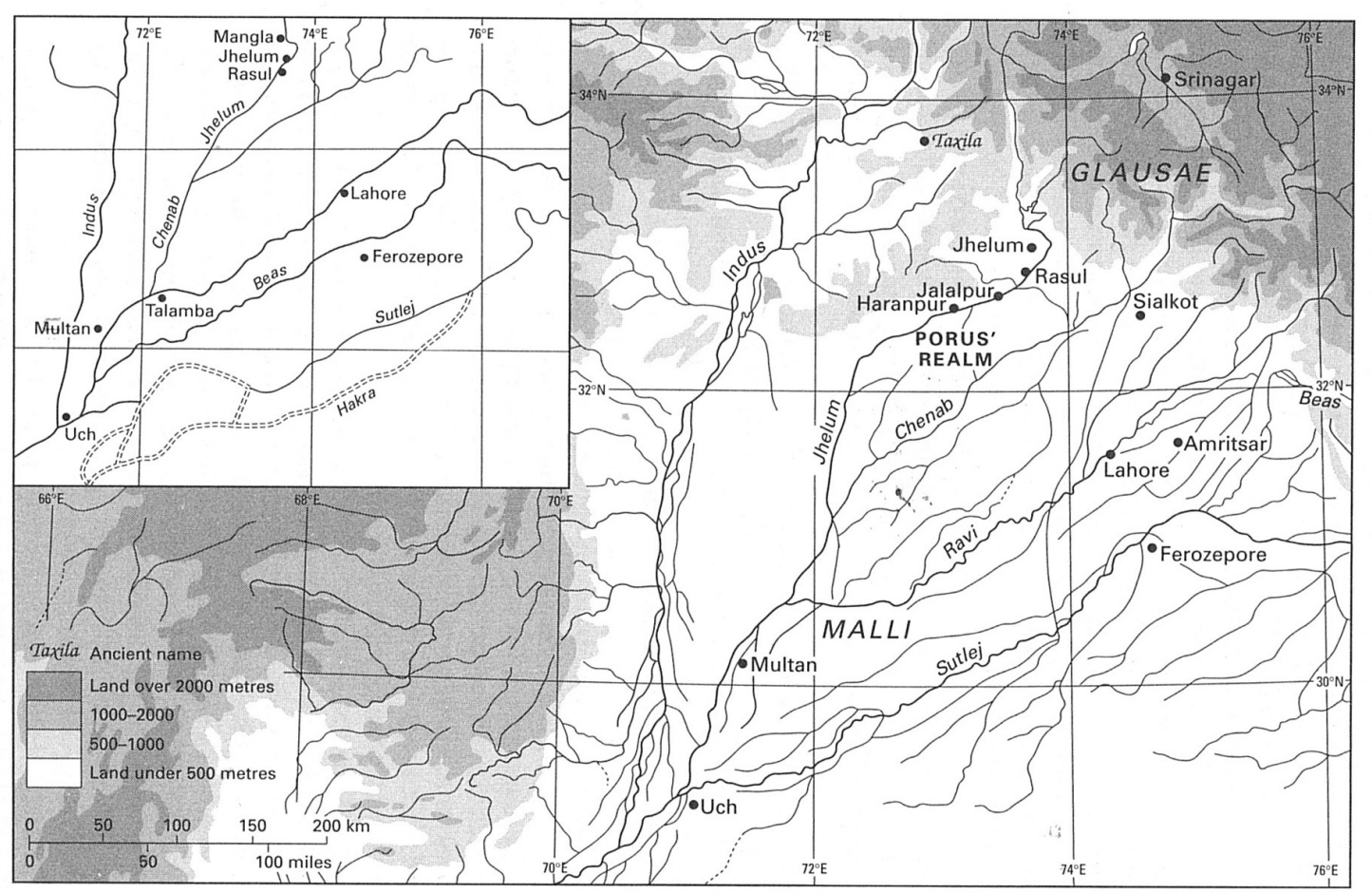

Fig. 2. The Punjab. Present-day topography with (inset) conjectural approximation of the river system in the Antiquity. 